\title{
Incidence of herpes simplex virus types 1 and 2 isolated in patients with herpes genitalis in Sheffield
}

\author{
I G BARTON,* G R KINGHORN,† S NAJEM,* L S AL-OMAR,* AND C W POTTER* \\ From the *Department of Virology, University of Sheffield Medical School; and the †Department of \\ Genitourinary Medicine, Royal Infirmary, Sheffield
}

SUMMARY Thirty-one strains of herpesvirus (HSV), isolated from patients presenting with the $\overrightarrow{\omega^{\omega}}$ clinical features of herpes genitalis, were typed by polypeptide analysis of virus proteins in sodiumo dodecyl sulphate polyacrylamide gels. Nineteen $(61 \cdot 3 \%)$ of the isolates were shown to be HSV type 1 and $12(38 \cdot 7 \%)$ HSV type 2 . There was no obvious difference in the incidence of HSV-1 in ${ }_{-}^{\circ}$ primary or recurrent infections and no apparent correlation between the genital site of isolation $\stackrel{+}{+}$ and virus type. The high incidence of genital HSV-1 infection in this group of patients is probablyo due to the increased practice of oro-genital contact and has possible implications for the future $\rightarrow$ development of drugs and vaccines in the control of genital herpes.

\section{Introduction}

Herpesvirus hominis (HSV) is becoming an increasingly common cause of genital infections. Despite the development of circulating antibodies to the virus many people develop recurrent infections, usually at or close to the site of primary infection but sometimes remote from it. ${ }^{1}$

Herpesvirus hominis may be divided into HSV type 1 (HSV-1) and HSV type 2 (HSV-2) by serological criteria, and it is generally accepted that there is a difference in the site of involvement and modes of transmission for the two serotypes. ${ }^{23}$ Thus, HSV-1 is usually transmitted non-venereally and affects non-genital sites, including the mouth, lips, skin above the waist, eyes, and brain; HSV-2 is most often transmitted venereally causing infection of the genitalia and skin below the waist. Nahmias and Starr ${ }^{1}$ found that $89 \%$ of female and $97 \%$ of male urogenital infections were due to type-2 virus. Other reports, however, indicate that HSV-1 may play a greater part in genital infections than was previously thought. In a survey in Edinburgh, Smith, Peutherer, and Robertson ${ }^{4}$ found 14 of $64(22 \%)$ female and 11 of $124(9 \%)$ male genital isolates to be HSV-1; in the United States Kaufman ${ }^{5}$ isolated HSV-1 from nine of $67(13.4 \%)$ genital infections; and in a Japanese study 23 of $53(43 \%)$ genital isolates from female patients were found to be HSV-1. ${ }^{6}$

Address for reprints: Dr I G Barton, Department of Virology, University of Sheffield Medical School, Beech Hill Road, Sheffield S10 2RX

Accepted for publication 6 July 1981
Previous studies of the incidence of HSV-1 in genital infections have relied on the use of kinetic or quantal neutralisation tests or immunofluorescence $e_{\infty}$ to type the virus ${ }^{78}$; these tests are often difficult to. perform, and the results are not always clear-cut. InV this study viruses were typed by analysis of the polypeptides present in infected cells using sodium $\bar{O}$ dodecyl sulphate polyacrylamide gels (SDS-PAGE) since there are many reports of distinct intertypic differences between HSV-1 and HSV-2 structural and infected cell polypeptides. ${ }^{910}$ This technique 3 allows unequivocal identification of HSV-1 andHSV-2 strains. In addition, 25 of the isolates described in this report have also been typed by digestion of virus DNA with restriction enzymes and: separation of the resultant fragments on agarose gels. $\frac{5}{3}$ Since HSV-1 and HSV-2 virus DNA have been. shown to have no coincident sites for any of the? restriction enzymes which have been tested, they give easily identifiable patterns on electrophoresis, and? this typing method again gives unequivoca results. ${ }^{11-13}$ Using these techniques the incidence of?. HSV-1 and HSV-2 in genital lesions was studied in aN series of patients attending the sexually transmitted diseases clinic in Sheffield.

\section{Materials and methods}

TISSUE CULTURE

BHK-21 (C13) cells (obtained from Flow Laboratories, Irvine, Scotland) were grown as monolayers in Glasgow modified Eagle's medium con- $\frac{0}{0}$ taining $10 \%(\mathrm{w} / \mathrm{v})$ tryptose phosphate broth an $10 \%(\mathrm{v} / \mathrm{v})$ newborn-calf serum. Cells were subcultured at regular intervals on a split ratio basis 


\section{VIRUSES}

HSV-1 (71-15) and HSV-2 (333) (obtained from F Rapp, Milton S Hershey Centre, Pennsylvania, USA) were propagated at low multiplicity in BHK-21 cells.

\section{ISOLATION FROM SWABS}

Swabs were taken of vesicular fluid or secretions from ulcerated genital lesions and immediately placed in a transport medium. On receipt this was divided into aliquots and stored at $-80^{\circ} \mathrm{C}$ until used for inoculation of cells.

Confluent cultures of cells in 2-oz or 4-oz glass medical flats were inoculated with $0 \cdot 5-1 \cdot 0 \mathrm{ml}$ of transport medium. The inoculum was adsorbed for one hour at $37^{\circ} \mathrm{C}$, the monolayer washed once with Eagle's minimal essential medium containing $2 \%$ (v/v) newborn-calf serum (EMM), and $10 \mathrm{ml}$ EMM then added to each bottle. The cells were maintained at $37^{\circ} \mathrm{C}$ with changes of medium every 3-5 days and observed daily for cytopathic changes (CPE). The monolayers were observed for a minimum of 14 days or until cell degeneration occurred. Cultures which showed $75 \%$ CPE were frozen at $-80^{\circ} \mathrm{C}$ until harvested.

\section{PREPARATION OF VIRUS STOCKS}

Positive cultures were thawed at $37^{\circ} \mathrm{C}$, the cells scraped into the medium, and the cell suspension sonicated at full power for 30 seconds using an MSE ultrasonic disintegrator. After cell disruption to release intracellular virus, the suspension was centrifuged for 10 minutes at $2000 \times g$ and the supernatant containing the released virus stored in 1-2 ml aliquots at $-80^{\circ} \mathrm{C}$. Viruses were passed 1-3 times in BHK-21 to increase the titre; the final virus pool was prepared by inoculating confluent monolayers of BHK-21 cells in 4-oz medical flats with $0 \cdot 01-0 \cdot 1$ plaque-forming units (pfu) per cell, and the cells harvested after 48 hours' incubation.

\section{VIRUS TITRATION}

For the determination of an infectivity titre, confluent monolayers in $5-\mathrm{cm}$ plastic Petri dishes (Sterilin, Middlesex) were inoculated with $0.1 \mathrm{ml}$ of an appropriate virus dilution. The virus was allowed to adsorb for one hour at $37^{\circ} \mathrm{C}$ and then $5 \mathrm{ml}$ of EMM containing $0 \cdot 8 \%$ carboxymethylcellulose was added to each dish. The dishes were further incubated at $37^{\circ} \mathrm{C}$ in an atmosphere of $5 \% \mathrm{CO}_{2}$ in air for 3-4 days; after this time the cells were fixed with $10 \%$ formol saline, stained with Leishman's stain, and the plaques counted.

LABELLING OF INFECTED CELL POLYPEPTIDES The labelling and preparation of infected cell polypeptides with ${ }^{35} \mathrm{~S}$-methionine in BHK-21 cells was performed as described by Lonsdale et al. ${ }^{14}$

\section{GEL ELECTROPHORESIS}

Samples containing equal numbers of trichloracetic acid precipitable counts were analysed on $18 \times 14 \mathrm{~cm}$ slab gels of $8 \cdot 5 \%$ acrylamide with a $5 \%$ stacking gel using the discontinuous buffer system of Laemelli. ${ }^{15}$ A set of proteins of known molecular weight (obtained from Pharmacia, Hounslow, Middlesex) were included in each gel together with the ${ }^{35} \mathrm{~S}$-methionine-labelled infected cell polypeptides of the laboratory strains of HSV-1 (71-15) and HSV-2 (333). Electrophoresis of the gels and the procedures used in staining and destaining were the same as described by Lonsdale et al. ${ }^{14}$ Gels were dried under vacuum using a Bio-Rad gel drier and exposed to $x$-ray film for varying lengths of time.

\section{PATIENTS}

The first 21 specimens were taken from consecutive patients with clinically obvious genital herpes seen between March and May 1980. This selection favoured the inclusion of patients with severe primary genital infections. The remaining 10 patients were seen between 29 October and 11 November 1980; during this period consecutive patients who presented with any form of genital ulceration were routinely tested for herpes virus. Except for patients 13 and 28 the cases were unrelated.

\section{Results}

\section{VIRUS IDENTIFICATION}

Virus samples labelled with ${ }^{35} \mathrm{~S}$-methionine were electrophoresed in $8.5 \%$ polyacrylamide gels as described above; a typical gel is shown in the figure. The principal feature used to identify the strain of virus was the molecular weight of the major capsid protein which is greater in HSV-2 than HSV-1. ${ }^{910}$ All the strains of HSV-1 arialysed also gave rise to a heavily labelled band of molecular weight $122 \mathrm{~K}$ which was absent from all the strains of HSV-2 examined. Although several differences between both virion and infected cell polypeptides have been reported, ${ }^{9} 10$ these were not always apparent in the gel system used. To confirm the accuracy of this method of typing the virus, 25 isolates were also typed by the restriction enzyme technique of Lonsdaie. ${ }^{16}$ In all the 25 isolates examined the polypeptide and restriction endonuclease analysis were in agreement.

\section{CLINICAL ISOLATES}

A total of 31 isolates from both male and female patients was typed; the source and the identification of virus type is shown in table 1 . Nineteen $(61 \%)$ of the strains were of HSV-1, as shown by virus polypeptide and restriction enzyme analysis. Analysis of the relationship between the virus type and the nature 


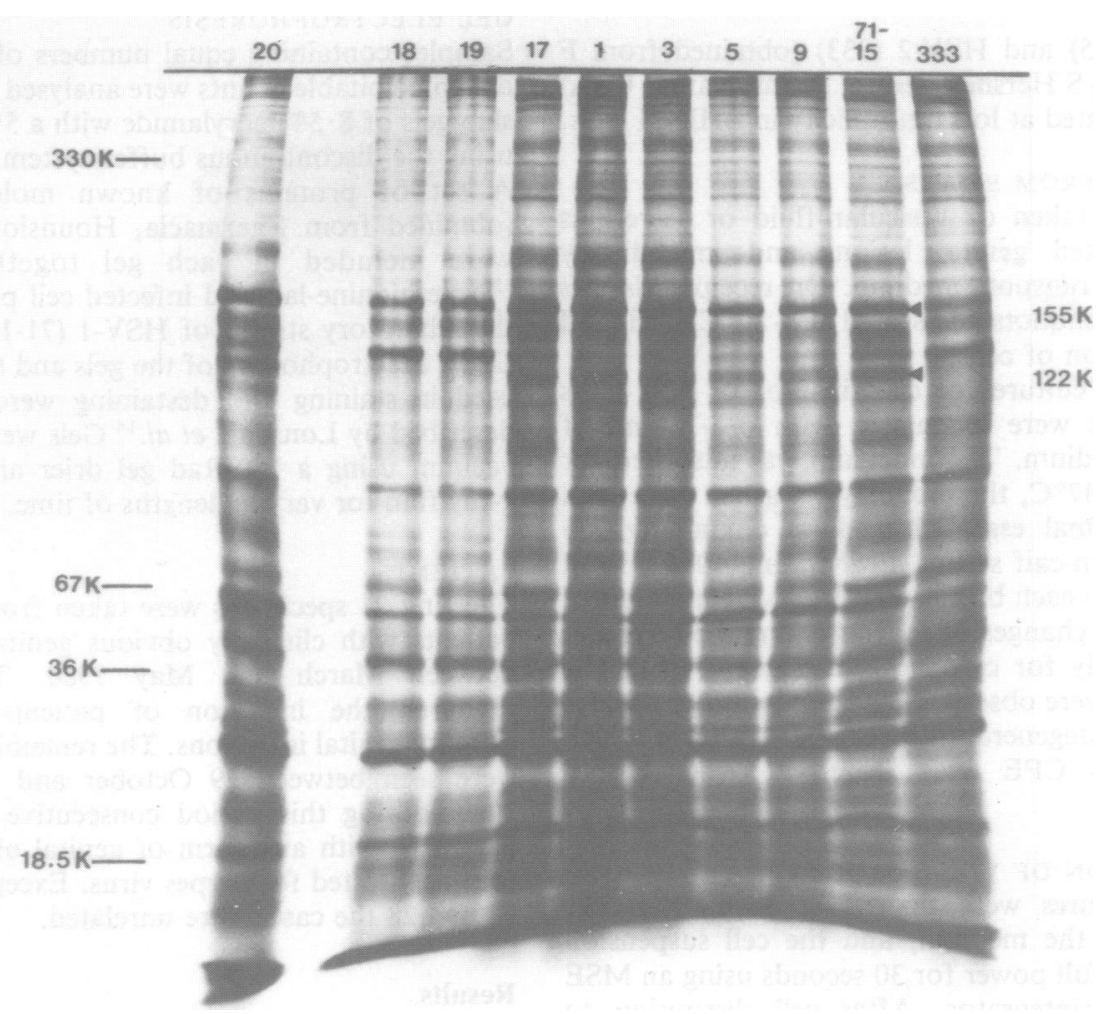

FIGURE Sodium dodecyl sulphate polyacrylamide gel electrophoresis showing two strains of HSV-2 (18 and 19), six strains of $H S V-1(20,17,1,3,5$, and 9), and the laboratory strains of $H S V-1(71-15)$ and $H S V-2$ (333). The position of the standard proteins of known molecular weight (thyroglobulin $330 \mathrm{~K}$, bovine serum albumin $67 \mathrm{~K}$, lactate dehydrogenase $36 \mathrm{~K}$, and ferritin $18.5 \mathrm{~K}$ ) are shown together with the major capsid polypeptide of HSV-1 (molecular weight $155 \mathrm{~K}$ ) and the highly labelled band of molecular weight $122 \mathrm{~K}$ used in typing the isolates.

of the genital lesion showed no apparent correlation; however, most of the isolates from men with primary infections were type 1 . The distribution of types among primary and recurrent infections is shown in table II. There was no marked difference between the incidence of HSV-1 in primary (14/22) and recurrent $(5 / 9)$ infections.

\section{Discussion}

Herpes genitalis is a disease which has increased in incidence in recent years; the infection is traditionally held to be associated with HSV-2, and this virus serotype is also considered an aetiological agent of carcinoma of the cervix. ${ }^{17}$ The results of the present study do not confirm the marked association of genital herpes with the HSV-2 serotype reported by other workers. Thus, HSV-1 was recovered from genital sites with a much greater frequency than has previously been supposed and was the agent of both primary and recurrent genital infections in bothb sexes.

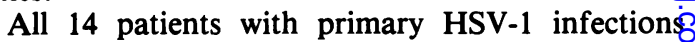
admitted orogenital contact compared with four of eight of those with HSV-2 infections. Oro-genitab contact was admitted less frequently by those with recurrent genital herpes. Patients with HSV-1 isolates? admitted to fewer partners in the month before thei attendance than did those with HSV-2 isolates. Fouro teen of the $19(74 \%)$ patients from whom HSV-1 was isolated admitted a single partner only comparedu with five of the $12(42 \%)$ with HSV-2 isolates. In one instance HSV-1 was isolated from the cervix of aे woman who had presented as the contact of a mark who had previously been seen with primary genital? herpes; in this case transmission was probably from the female patient's oral herpes via oro-peniles contact, with subsequent transmission of virus to the cervix from the primary penile infection. The hight incidence of genital infections with HSV-1 in this 
TABLE I Incidence of $H S V-I$ and $H S V-2$ isolated from a series of 31 patients

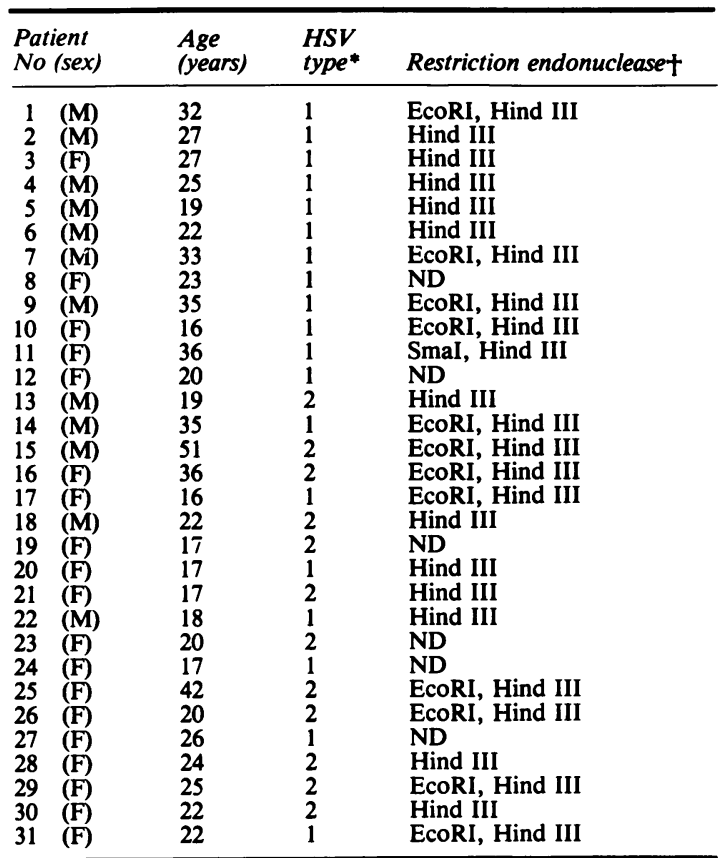

* Virus type as determined by analysis of infected cell polypeptides tRestriction endonuclease used to confirm virus type.

$\mathrm{ND}=$ not done

TABLE II Incidence of primary and recurrent infections with HSV

\begin{tabular}{|c|c|c|c|c|c|}
\hline \multirow[b]{2}{*}{$H S V$} & \multicolumn{2}{|c|}{ Primary infections } & \multicolumn{2}{|c|}{ Recurrent infections } & \multirow{2}{*}{$\begin{array}{c}\text { Total } \\
(\%)\end{array}$} \\
\hline & Men & Women & Men & Women & \\
\hline $\begin{array}{l}\text { Type } 1 \\
\text { Type } 2\end{array}$ & $\begin{array}{l}6 \\
1\end{array}$ & $\begin{array}{l}8 \\
7\end{array}$ & $\begin{array}{l}3 \\
2\end{array}$ & $\begin{array}{l}2 \\
2\end{array}$ & $\begin{array}{l}19(16 \cdot 3) \\
12(38 \cdot 7)\end{array}$ \\
\hline
\end{tabular}

group of patients may be the result of increasing acceptability and practice of oro-genital contact. This may be one factor which could explain why genital herpes infections appear to be increasing at a much greater rate than other sexually transmitted diseases. Transmission of HSV-1 by oro-genital contact may also explain the occurrence of herpes genitalis within sexually stable relationships where there have been no other partners.

The high frequency of HSV-1 isolation found in this group of patients has important implications if the results are confirmed in other centres. Firstly, the susceptibility of the two serotypes to treatment with antiviral agents varies; in general HSV-1 is more susceptible to antiviral drugs than HSV-2. ${ }^{18} 19$ Therefore, in the assessment of antiviral compounds, reference must be made to the virus serotype since this may influence the results. Secondly, the proposed development of an HSV-2 vaccine for the control of herpes genitalis may have to be reconsidered should HSV-1 be shown to be an important aetiological agent of genital infection. Thirdly, the possible importance of $\mathrm{HSV}-2$ as an aetiological agent of carcinoma of the cervix has been extensively reviewed ${ }^{13}{ }^{17}$; but the present findings suggest that a similar role for HSV-1 should be investigated.

The work reported in this paper was supported by a grant from the Yorkshire Cancer Research Campaign.

\section{References}

1. Nahmias AJ, Starr SE. In: Infectious Diseases Hoeprich PD, ed. London: Harper and Row, 1979; 726-35.

2. Nahmias A, Dowdle W. Antigenic and biologic differences in Herpesvirus hominis. Prog Med Virol 1968; 10:110-59.

3. Dowdle W, Nahmias A, Harwell R, Pauls F. Association of antigenic type of Herpesvirus hominis to site of viral recovery. J Immunol 1967;99:974-80.

4. Smith IW, Peutherer JF, Robertson DHH. Virological studies in genital herpes (letter). Lancet 1976; ii: 1089-90.

5. Kaufman RL, Rawls WE, Dixon R, Young RL. Clinical features of herpes genitalis. Cancer Res 1973;33:1446-51.

6. Kawana T, Kawaguchi T, Sakamoto S. Clinical and virological studies on genital herpes. Lancet 1976; ii:965.

7. Wheeler CE jun, Briggaman RA, Henderson RRJ. Discrimination between two strains (types) of herpes simplex by various modifications of the neutralization test. J Immunol 1969; 102: 1178-92.

8. Nahmias A, Chiang W, Del Buano I, Duffey C. Typing of Herpesvirus hominis strains by indirect immunofluorescent technique. Proc Soc Exp Biol Med 1969; 132:386-90.

9. Cassai EN, Sarimento M, Spear PG. Comparison of the virion proteins specified by herpes simplex virus type 1 and $2 . J$ Virol 1975; 16: 1327-31.

10. Powell KL, Mirkovic R, Courtney RJ. Comparative analysis of polypeptides induced by type 1 and type 2 strains of herpes simplex virus. Intervirology 1977;3:13-29.

11. Wilkie NM. Physical maps for herpes simplex virus type DNA for restriction endonucleases. Hind III, Hpa-I and X-bad. J Virol 1976; 20:222-33.

12. Skare J, Summers WP, Summers WC. Structure and function of herpes genomes: I Comparison of five HSV-1 and two HSV-2 strains by cleavage of their DNA with EcoRI restriction endonuclease. J Virol 1975; 15:726-32.

13. Cortini R, Wilkie NM. Physical maps for HSV type 2 DNA with five restriction endonucleases. J Gen Virol 1978; 39:259-80.

14. Lonsdale DM, Brown SM, Subak-Sharpe JH, Warren KG, Koprowski J. The polypeptide and DNA restriction enzyme profiles of spontaneous isolates of herpes simplex virus type 1 from explants of human trigeminal, superior cervical and vagus ganglia. J Gen Virol 1979; 43:151-71.

15. Laemelli IK. Cleavage of structural proteins during the assembly of the head of bacteriophage T4. Nature 1970; 214:1334-6.

16. Lonsdale DM. A rapid technique for distinguishing herpes simplex type 1 and type 2 by restriction enzyme technology. Lancet 1979; i: 849-50.

17. Royston I, Aurelian L. The association of genital herpes with cervical atypia and carcinoma in situ. Am J Epidemiol 1970;91:531-40.

18. De Clereq E, Descamps J, De Somer P, Barr PJ, Jones AS, Walker RT. (E)-5-(2-bromovinyl)-2' deoxyuridine: potent and selective anti-herpes agent. Proc Natl Acad Sci (USA) 1979; 76:2947-51.

19. Park A, Pavan-Langston D, Hettinger ME, et al. Topical therapeutic efficacy of 9-(2-hydroxymethyl) guanine and 5 '-iodo-5'-amino-2', 5'dideoxyuridine on oral infection with herpes simplex virus in mice. $J$ Infect Dis 1980; 141:575-9. 